\title{
PEMBUATAN SISTEM INFORMASI MANAJEMEN BENGKEL DI SEKOLAH MENENGAH KEJURUAN NEGERI 3 YOGYAKARTA
}

\author{
Syahrina Ramadhina \\ Program Studi Teknik Audio Video SMK Negeri 3 Yogyakarta \\ Jl. Rw. Monginsidi No 2, RT.17/RW.4, Cokrodiningratan, Jetis, Yogy akarta \\ syahrinaramadhina@yahoo.com
}

\begin{abstract}
The purpose of the study is to develop information system which can support the users in handling the management information system of Vocational High School Workshops. The study is categorized as the Educational Research Development $(R \& D)$. The research procedure used in conducting this study consists of some steps i.e.: need analysis, product design, product design development, product trial/product implementation, and product evaluation. In the development phase of product design, the software was tested for feasibility by alpha validation tests and beta testing. Further product assessment to determine the performance of the system involved the users consisting of the head of the workshop, technicians, teachers, and students of Workshop at SMK 3 Yogyakarta. Data were analyzed with descriptive statistics. The result of this study was the software named Sistem Informasi Manajemen Bengkel Kerja Sekolah Menengah Kejuruan, The Management Information System of the Vocational High School Workshop (SIMBA SMK 3 Yogyakarta). Results of the assessment stated that the product had met the criteria; clear, consistent, accurate, and reliable. It was indicated by the whole score rate reaching at 3.77 in good scale.
\end{abstract}

Key words: Workshop, Management Information System, Vocational High School

\begin{abstract}
ABSTRAK
Penelitian ini bertujuan untuk mengembangkan sistem informasi yang dapat mendukung pengguna dalam memberikan pelayanan sistem informasi manajemen bengkel kerja Sekolah Menengah Kejuruan. Penelitian ini merupakan jenis penelitian pengembangan atau Research and Development (R\&D). Prosedur penelitian yang digunakan pada penelitian ini terdiri atas beberapa langkah meliputi analisis kebutuhan, desain produk, pengembangan desain produk, uji coba produk/implementasi produk, dan penilaian produk. Pada tahap pengembangan desain produk, pengujian kelayakan software dilakukan dengan cara validasi tes alpha dan tes beta. Selanjutnya dilakukan penilaian produk untuk mengetahui kinerja sistem menurut pengguna yang terdiri dari kepala bengkel, teknisi, guru, dan siswa Bengkel Kerja di SMK Negeri 3 Yogyakarta. Analisis data menggunakan statistik deskriptif. Hasil penelitian ini adalah sebuah produk Software yang diberi nama Sistem Informasi Manajemen Bengkel Kerja Sekolah Menengah Kejuruan (SIMBA SMK Negeri 3 Yogyakarta). Produk yang telah disusun dinyatakan telah memenuhi kriteria jelas, konsisten, akurat, dan andal. Rerata penilaian secara keseluruhan mencapai 3,77 dalam skala baik.
\end{abstract}

Kata kunci: Bengkel Kerja, Sistem Informasi Manajemen, SMK

\section{PENDAHULUAN}

Peraturan Pemerintah Nomor 29 Tahun 1990b menyebutkan pendidikan di Sekolah Menengah Kejuruan (SMK) dapat dilihat dalam dua sisi yaitu pendidikan sebagai praktik dan pendidikan sebagai teori. Pendidikan sebagai praktik yakni seperangkat kegiatan atau aktivitas yang dapat diamati dan disadari dengan tujuan untuk membantu peserta didik agar memperoleh perubahan perilaku. Sementara pendidikan sebagai teori yaitu seperangkat pengetahuan yang tersusun secara sistematis dan berfungsi untuk menjelaskan, menggambarkan, meramalkan dan mengontrol berbagai gejala dan peristiwa pendidikan, baik yang bersumber dari pengalaman (empiris) maupun dari hasil perenungan yang mendalam untuk melihat makna pendidikan dalam konteks 
yang lebih luas. Diantara keduanya memiliki keterkaitan dan tidak bisa dipisahkan. Praktik harus berlandaskan pada teori. Demikian pula, teori bercermin dari praktik. Perubahan yang terjadi dalam praktik dapat memberikan imbas pada teori.

Proses pembelajaran teknik dan kejuruan diarahkan untuk menemukan inti materi pelajarannya dengan pendekatan pembelajaran praktis. Untuk itu diperlukan sarana bengkel kerja SMK yang layak sebagai penunjang pembelajaran teknik kejuruan. Joel Tadjo, 1995 menjelaskan pada hakikatnya bengkel kerja SMK merupakan tempat berlatih untuk meningkatkan keterampilan baik dalam hal pembuatan benda kerja, pemeliharaan dan perbaikan maupun pengujian kebenaran suatu teori yang ditunjang oleh peralatan dan infrastruktur yang lengkap. Semua kegiatan di Bengkel Kerja SMK memerlukan administrasi yang teratur dan terorganisir, sehingga bengkel dapat ditata dan berfungsi secara optimal.

Abdul Kadir, 2003 menerangkan pengelolaan administrasi bengkel kerja yang terdapat di SMK meliputi 5 aspek penting yaitu sumber daya manusia, mesin atau peralatan, material atau bahan baku, uang, dan lingkungan pendukung kerja praktik di bengkel. Pengelolaan yang dimaksud adalah tentang bagaimana sistem penataan dan perawatan diterapkan agar bengkel kerja dapat digunakan oleh siswa secara optimal untuk meningkatkan kualitas pembelajaran. Pengelolaan Bengkel Kerja SMK di bidang sumber daya manusia adalah penataan terhadap guru/instruktur, siswa, pengelola, teknisi dan SDM terkait, kemudian pengelolaan materialnya adalah penataan terhadap jenis dan kualitas, distribusi, jumlah, pengadaan, stok material, dan penyimpanan. Demikian pula pengelolaan terhadap mesin, pengelolaan uang dan lingkungan kerja praktik. Semuanya harus dikelola dan ditata secara detail, rinci, dan terkendali. Hal ini sesuai dengan kebijakan pemerintah dalam perluasan akses terhadap pendidikan di SMK.

Perkembangan dalam bidang pendidi-kan dapat dilihat pada salah satu sekolah yang berada di Daerah Istimewa Yogyakarta yaitu SMK Negeri 3 Yogyakarta. Sekolah ini memiliki bengkel untuk praktik yang berlokasi di lingkungan SMK N 3 Yogyakarta. Permasalahan yang sering muncul adalah pencatatan data barang di dalam bengkel ini masih menggunakan kertas dan pulpen, pencarian data di dalam catatan ini memakan waktu yang cukup lama, dan saat membuka catatan, tangan toolman/teknisi yang akan membuka catatan dalam kondisi kotor atau basah yang dapat merusak catatan itu sendiri.

Secara teknis SMK Negeri 3 Yogyakarta termasuk kelompok teknologi dan industri sebagai lembaga penyelenggara pendidikan dapat diidentikkan sama dengan sebuah industri. Keduanya menghasilkan suatu produk tertentu yang senantiasa dijaga mutu dan kualitasnya. Salah satu fasilitas di SMK yang dapat meningkatkan mutu adalah tersedianya bengkel praktik dan kelengkapannya yang selalu terjaga kualitasnya melalui perawatan dan penataan yang benar. Tujuan dari perawatan dan penataan Bengkel Kerja SMK tersebut adalah agar dapat digunakan dengan cepat, akurat, relevan, aman, dan nyaman, sehingga dapat mendukung produktivitas kerja praktik, dan pembudayaan kerja efektif, efisien dan produktif. Jika sistem perawatan dan penataan Bengkel Kerja SMK dilakukan dengan baik maka bengkel tersebut dapat berfungsi secara optimal.

Oleh karena itu Bengkel Kerja SMK memerlukan suatu sistem informasi yang tepat dan cepat dalam menata administrasi Bengkel Kerja SMK. Untuk mendapatkan informasi yang diinginkan tentunya harus menggunakan sistem informasi yang baik dan handal. Sistem informasi yang dimaksud adalah suatu sistem yang menyediakan informasi bagi semua tingkatan dalam organisasi tersebut kapan saja diperlukan. Sistem ini menyimpan, mengambil, mengubah, mengolah dan mengkomunikasikan informasi yang diterima dengan menggunakan sistem informasi atau peralatan sistem lainnya.

Sistem Informasi dirancang untuk mempermudah dalam pengelolaan dan pe- 
nyimpanan data maka dapat menghasilkan suatu informasi yang tepat dan akurat. Adanya sistem informasi yang tepat dan akurat dapat mengurangi terjadinya permasalahan dan kesalahan yang tidak diinginkan sehingga dapat meningkatkan kinerja yang lebih efisien dan cepat, salah satunya adalah pengelolaan dan penyimpanan data inventaris barang. Pengelolaan dan penyimpanan data inventaris barang biasanya hanya dilakukan secara manual yaitu dengan menggunakan buku besar yang digunakan untuk mencatat barang-barang yang ada. Apabila ada pihak yang membutuhkan data inventaris tahun sebelumnya, maka sulit untuk mencari keterangan dimana dan apa saja data barang yang dibutuhkan tersebut.

Permasalahan lainnya adalah ketika proses pembelajaran praktik berlangsung, sering kali peralatan praktik yang dipinjamkan ketika dikembalikan jumlahnya menjadi berkurang, hal ini dikarenakan oleh beberapa faktor, baik faktor dari siswa, faktor dari luar, maupun faktor dari teknisi itu sendiri yang kurang maksimal dalam memberikan pelayanan.

Faktor dari siswa biasanya ketika praktik berlangsung ada siswa yang sengaja membawanya pulang dengan maksud memilikinya ataupun mempunyai tujuan-tujuan tertentu. Faktor dari luar dapat berasal dari guru-guru ataupun karyawan dan pihak-pihak lain yang sering kali melakukan peminjaman peralatan untuk digunakan pada kebutuhan tertentu dan sering kali lupa untuk mengembalikan. Sedangkan faktor dari teknisi yang kadang malas dalam mengecek ulang ketika proses pengembalian peralatan setelah kegiatan pembelajaran praktik berlangsung karena peralatan yang dipinjamkan begitu banyak. Apabila hal ini terus berlangsung maka pada akhirnya nanti pembelajaran secara praktik lama-kelamaan akan terganggu karena peralatan-peralatan praktik yang semakin berkurang kuantitasnya.

Dengan berkurangnya peralatan praktik secara otomatis siswa tidak dapat berpraktik maksimal karena harus bergantian menggunakan peralatan praktik yang ada. Karena penggunaan peralatan praktik yang bergantian sudah tentu masalah waktu juga akan ikut terpengaruh yaitu waktu yang digunakan untuk praktik satu jenis keahlian dapat menjadi lebih lama bila dibandingkan jika sekolah mempunyai peralatan praktik yang lengkap sehingga antrian penggunaan peralatan praktik tidak perlu terjadi. Dengan terganggunya kegiatan praktik siswa bisa saja tidak memperoleh kesempatan melakukan praktik, keadaan ini akan berakibat pada berkurangnya kompetensi yang bisa dikuasai siswa.

Selain masalah di atas, permasalahan lain yang muncul berkaitan dengan kegiatan pembelajaran praktik bagi siswa adalah masalah ketersediaan barang-barang habis pakai yang digunakan untuk menunjang ketika praktik berlangsung. Ketika pembelajaran praktik berlangsung tentu saja akan menghabiskan barang-barang habis pakai. Seorang teknisi berkewajiban memantau keberadaan bahan habis pakai tersebut sehingga ketersediaannya selalu ada ketika dibutuhkan. Apabila persediaan barang habis pakai tersebut habis tentu saja juga akan mengganggu kegiatan praktik siswa. Dengan demikian teknisi harus mempunyai catatan penggunaan barang-barang habis pakai tersebut sehingga dapat dijadikan acuan untuk pengadaan dan laporan pertanggungjawaban kepada atasan.

Dari segi pengaturan jadwal terkadang juga ditemukan permasalahan di dalamnya. Diantaranya adalah pengaturan jadwal yang sering berbenturan atau tidak match antara ruang yang digunakan, jadwal guru yang mengajar praktik, serta waktu praktik. Ketidakjelasan ini memakan waktu yang relatif lama dan pada akhirnya menyebabkan waktu praktik siswa menjadi berkurang. Berkurangnya waktu praktik ini sudah tentu akan merugikan proses pembelajaran.

Bersumber dari uraian-uraian di atas dapat diketahui bahwa kelancaran proses pembelajaran praktik siswa sangat penting untuk meningkatkan mutu pendidikan pada jenjang SMK, maka masalah yang muncul di atas harus segera diatasi. Cara mengatasi 
permasalahan tersebut salah satunya adalah dengan bantuan teknologi yaitu dengan bantuan komputer yang dapat digunakan untuk membantu pengelolaan bengkel kerja yang ada di SMK menjadi lebih terkendali dan terorganisir dengan baik.

Oleh karena itu menarik untuk mengadakan penelitian tentang bagaimana mengembangkan suatu produk menggunakan teknologi komputer yang dapat digunakan untuk mengatasi segala permasalahan yang berkaitan dengan pengelolaan dan penataan bengkel kerja demi keberlangsungan pembelajaran praktik di SMK.

Penyelenggaraan Sekolah Menengah Kejuruan (SMK) didasarkan atas ketentuan yang ada pada Undang-Undang Republik Indonesia No.2 tahun1989, pasal 11 ayat (1) dan (3) tentang Sistem Pendidikan Nasional Bab IV yang berbunyi sebagai berikut: "Jenis pendidikan umum, pendidikan kejuruan, pendidikan luar biasa, pendidikan kedinasan, pendidikan keagamaan, pendidikan akademik, dan pendidikan professional.". Sekolah Menengah Kejuruan berdasarkan tingkatan pendidikan setara dengan sekolah menengah atas, akan tetapi keduanya mempunyai tujuan yang berbeda.

Sekolah Menengah Kejuruan memiliki karakteristik khusus yang membedakan dengan sekolah lainnya. Tujuan institusional SMK lebih menekankan pada penguasaan kemampuan yang bersifat praktis agar siap pakai di dunia industri. Kurikulum di SMK menitik beratkan pada penguasaan keterampilan sehingga strategi pembelajarannya lebih ditekankan pada praktik daripada teori.

Sekolah Menengah Kejuruan menyelenggarakan pendidikan dan pelatihan berbagai program studi keahlian sesuai dengan kebutuhan lapangan kerja. Mengingat begitu banyak ragam keahlian kejuruan dan teknologi serta melihat bidang-bidang pekerjaan yang dikembangkan saat ini, maka berdasarkan Spektrum Kurikulum Pendidikan Menengah Kejuruan SMK 2013, bidang studi keahlian di SMK dibagi menjadi delapan kelompok besar yaitu: (1) Bidang Studi Keahlian Teknologi dan Rekayasa; (2) Bidang Studi Keahlian Informasi dan Komunikasi; (3) Bidang Studi Keahlian Kesehatan; (4) Bidang Studi Keahlian Agrobisnis dan Agroteknologi; (5) Bidang Studi Keahlian Perikanan dan Kelautan; (6) Bidang Studi Keahlian Bisnis Dan Manajemen; (7) Bidang Studi Keahlian Pariwisata; dan (8) Bidang Studi Keahlian Seni Dan Kerajinan.

SMK memiliki suatu keistimewaan yang tidak dimiliki oleh Sekolah Menengah Umum (SMU). Keistimewaaan tersebut adalah berupa sarana dan prasarana Bengkel Kerja Sekolah yang berfungsi dalam penyelenggaraan pendidikan keterampilan dan teknologi. Pengertian Bengkel Kerja Sekolah begitu luas bila ditinjau dari jenis kegiatan yang dilakukan dan sarana yang digunakan, (Joel Tadjo, 1995, p.1) menjelaskan : (1) Sebagai tempat latihan untuk mening-katkan keterampilan; (2) Sebagai tempat melakukan kegiatan dalam pembuatan bahan baku menjadi barang jadi; (3) Sebagai tempat melakukan perbaikan suatu barang atau peralatan yang rusak sehingga berfungsi kembali; dan (4) Sebagai tempat melakukan pengujian atau penelitian suatu objek secara terorganisir.

\section{Sistem Informasi Manaje men}

Data merupakan bahan utama dari pekerjaan sistem informasi. Data adalah kata jamak (plural) dan kata tunggalnya (singular) adalah datum yang berasal dari bahasa Latin yang berarti fakta, kenyataan, kejadian, atau peristiwa. Secara terperinci, menurut (Kristanto, 2008:7) data adalah:

1) Kenyataan yang menggambarkan suatu kejadian-kejadian dan kesatuan nyata. Kejadian-kejadian (event) adalah sesuatu yang terjadi pada saat tertentu; dan

2) Data menggambarkan suatu kejadian yang sedang terjadi, dimana data tersebut akan diolah dan diterapkan dalam sistem menjadi input yang berguna dalam suatu sistem

Kristanto, 2008 menjelaskan "suatu sistem pada dasarnya adalah sekumpulan dari 
elemen-elemen yang saling berinteraksi atau bekerja sama untuk mencapai suatu tujuan tertentu". Sistem juga merupakan kumpulan elemen-elemen yang saling terkait dan bekerja sama untuk memproses masukan (input) yang ditujukan kepada sistem tersebut dan mengolah masukan tersebut sampai menghasilkan keluaran (output) yang diinginkan sehingga fungsi sistem yang utama adalah menerima masukan, mengolah masukan, dan menghasilkan keluaran.

Manajemen adalah proses atau kegiatan yang dilakukan oleh seseorang atau pemimpin atau manajer di dalam organisasi untuk mencapai tujuan bersama. Secara operasional dapat didefinisikan sebagai suatu proses mengkoordinasikan, mengintegrasikan, menyederhanakan dan mensinkronisasikan sumber daya manusia, material dan metode (Men, Material, Methods/3M) dengan mengaplikasikan fungsi-fungsi manajemen seperti, perencanaan, pengorganisasian, penggiatan, pengawasan dan lain-lain agar tujuan organisasi dapat tercapai secara efektif dan efisien. Untuk menjalankan fungsi-fungsi manajemen diperlukan dukungan data dan informasi serta akan menghasilkan data dan informasi pula. Kadir, 2003 menerangkan sistem informasi manajemen (SIM) atau Management Information Systems (MIS) adalah "sistem informasi yang digunakan untuk menyajikan informasi yang digunakan untuk mendukung operasi, manajemen, dan pengambilan keputusan dalam sebuah organisasi." Definisi lain menurut (Kristanto, 2008:29) sistem informasi manajemen merupakan "suatu sistem yang biasanya diterapkan dalam suatu organisasi untuk mendukung pengambilan keputusan dan informasi yang dihasilkan dibutuhkan oleh semua tingkatan manajemen atau dengan kata lain teknik pengelolaan informasi dalam suatu organisasi." Hal ini sejalan dengan pendapat (Reddy, Srinivasu, Rikkula, \& Rao, 2009:1) yang menyatakan bahwa:

Management Information System (MIS) provides information for the managerial activities in an organization. The main purpose of this research is, MIS provides accurate and timely information necessary to facilitate the decision-making process and enable the organizations planning, control, and operational functions to be carried out effectively. Management Information System (MIS) is basically concerned with processing data into information and is then communicated to the various Departments in an organization for appropriate decision-making. MIS is a subset of the overall planning and control activities covering the application of humans, technologies, and procedures of the organization. . The information system is the mechanism to ensure that information is available to the managers in the form they want it and when they need it.

Sistem Informasi Manajemen Bengkel adalah sistem yang mampu memberikan informasi yang merupakan hasil semua transaksi yang dilakukan oleh bengkel dimana satu sama lain saling berinteraksi mencapai tujuan yang telah ditargetkan oleh bengkel tersebut.

Informasi yang dibutuhkan tidak dilihat dari jumlah informasi yang dihasilkan, tetapi kualitas dari informasi (quality of information) tersebut karena tidak semua informasi berkualitas. Oleh sebab itu, sudah seharusnya dilakukan penyaringan terhadap informasi yang beredar atau yang dapat ditangkap.

Budi Sutedja (2002) memaparkan "Untuk membangun suatu sistem yang kompleks secara sistematis dan terintegrasi, dibutuhkan metodemetode pembangunan sistem agar dapat menuntun pembuat untuk menghasilkan suatu sistem yang standar." Para ahli telah mengembangkan beberapa metode berdasarkan pengalaman mereka dalam membangun Sistem Informasi, seperti metode prototype, daur hidup, dan spiral.

Prototype adalah suatu metode pengembangan sistem yang dapat membuat sesuatu program dengan cepat dan bertahap sehingga segera dapat dievaluasi oleh pemakai. Kadir, 2003:416 menjelaskan "Prototipe membuat proses pengembangan sistem 
informasi menjadi lebih cepat dan lebih mudah, terutama pada keadaan kebutuhan pemakai sulit untuk diidentifikasi." Bagi sistem berskala kecil, prototype dapat menghasilkan siklus hidup pengembangan sistem. Berikut ini adalah gambar atau skema metode prototype yaitu metode prototype 2 :

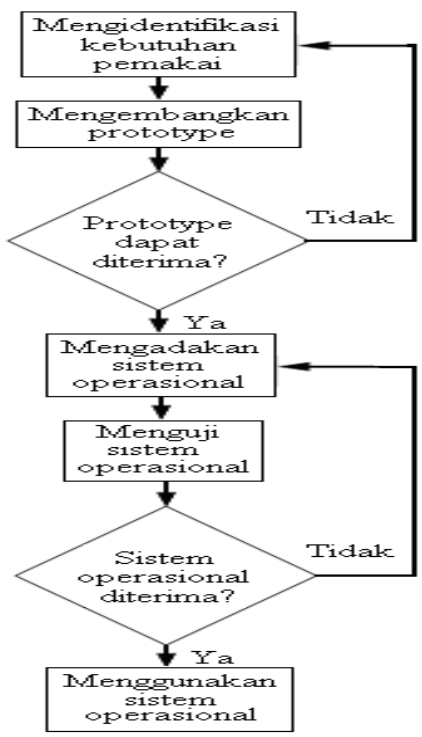

Gambar 1. Metode Prototype 2

(sumber: Budi Sutedja D. O., 2002, p.148)

\section{Siklus Daur Hidup Suatu Sistem (Systems Life Cycle)}

Proses pengembangan sistem melewati beberapa tahapan dari mulai sistem itu direncanakan sampai dengan sistem tersebut diterapkan, dioperasikan, dan dipelihara. Bila operasi sistem yang sudah dikembangkan masih timbul kembali permasalahan-permasalahan yang kritis serta tidak dapat diatasi dalam tahap pemeliharaan sistem, maka perlu dikembangkan kembali suatu sistem untuk mengatasinya dan proses ini kembali ke tahap pertama, yaitu tahap perencanaan sistem. Proses ini disebut dengan siklus hidup suatu sistem (systems life cycle). Konsep siklus hidup cocok dengan segala sesuatu yang lahir, tumbuh berkembang dan akhirnya mati. Pola ini juga berlaku untuk sistem berbasis komputer seperti pengolahan data, atau sistem pendukung keputusan (Decision Support System-DSS).
Pada dasarnya daur hidup pengembangan sistem informasi dapat melibatkan 3 (tiga) atau 5 (lima).tahapan, seperti gambar 2 berikut:

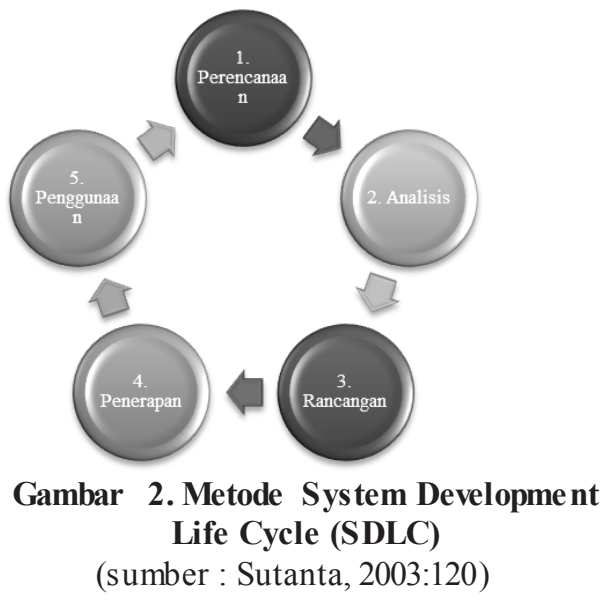

Prosedur pengembangan dilakukan setelah adanya analisis masalah dan potensi. Sesuai dengan model pengembangan yang digunakan, prosedur pengmbangan dalam penelitian ini diuraikan sebagai berikut:

Pada tahap ini dilakukan kegiatan untuk mengetahui adanya masalah, peluang, kesempatan yang memicu pengembangan sistem informasi. Kemudian menetapkan ruang lingkup pengembangan sistem dan kendalakendala yang akan berdampak pada pengembangan sistem. Mendefinisikan kebutuhan data dan informasi yang diperlukan dilakukan dengan mengkomunikasikan dengan pihak terkait yaitu kepala bengkel, toolman, dan guru/instruktur di Bengkel Kerja SMK yang bersangkutan. Analisis kebutuhan dilakukan dengan mempertimbangkan kelayakan teknis, operasi, jadwal, ekonomi dan hukum.

Pada tahap ini dilakukan kegiatan analisis terhadap sistem informasi administrasi bengkel Sekolah Menengah Kejuruan dengan mengamati prosedur, sistem pencatatan data, aliran data dan permasalahan yang mungkin ada untuk mengetahui kelemahan sistem, data yang dihasilkan dan keluarannya dalam menghasilkan sumber data. 


\section{Desain/Perancangan Sistem (System Design)}

Analisis sistem yang akan memikirkan bagaimana membentuk sistem baru yang diinginkan. Berdasarkan hasil analisis, kemudian dilanjutkan dengan melakukan perancangan sistem bertujuan untuk menentukan kebutuhan sistem yang akan dibuat. Tahap perancangan sistem merupakan tahap pemasukan ide atau gagasan guna memenuhi tujuan pengembangan sistem informasi sebagai persiapan untuk rancang bangun implementasi.

\section{Implementasi/Pene rapan Sistem}

Tahap untuk merealisasikan hasil desain/ perancangan sistem yang telah dilakukan sebelumnya ke dalam bentuk yang sebenarnya. Implementasi sistem meliputi: (a) Merencanakan waktu yang tepat untuk implementasi; (b) Mengumumkan rencana implementasi; (c) Mendapatkan sumberdaya perangkat keras dan lunak; (d) Menyiapkan database; (e) Menyiapkan fasilitas fisik; (f) Memberikan pelatihan dan workshop; (g) Menyiapkan saat yang tepat untuk cutover (peralihan sistem); dan (h) Penggunaan sistem baru

\section{Penggunaan/Review/Evaluasi Sistem}

Analis sistem masih perlu melakukan tindak lanjut berikutnya setelah sistem baru diimplementasikan. Analis sistem melakukan pengetesan penerimaan sistem (system acceptance test). Pengetesan ini dilakukan dengan data yang sebenarnya dalam jangka waktu tertentu bersama-sama dengan pengguna sistem. Setelah itu analis sistem bersama dengan pengguna melakukan diskusi untuk menentukan apakah sistem yang baru bisa diterima atau perlu diperbaiki lagi. Setelah sistem baru diterapkan, maka tahapan akhir yang harus dilakukan adalah perawatan. Perawatan sangat penting peranannya agar sistem baru yang dikembangkan tetap bisa dipergunakan untuk masa sekarang sampai masa yang akan datang.

\section{METODE}

Penelitian ini adalah penelitian pengembangan atau Research and Development (R\&D). (Borg \& Gall, 1983:772) menjelas-kan "pengertian penelitian dan pengembangan yaitu suatu proses yang digunakan untuk mengembangkan dan mengesahkan produk-produk yang berhubungan dengan pendidikan." Tahap penelitian dan pengembangan yang akan diterapkan selalu mengacu pada revisi hasil tindakan sebelumnya sehingga pada akhirnya diperoleh suatu produk pengembangan.

Uji coba produk dilaksanakan pada tanggal 8 November 2013 di BLPT Yogyakarta. Sedangkan pengambilan data penelitian penggunaan SIM Bengkel Kerja SMK dan penilaian produk menurut para pengguna yaitu kepala bengkel, teknisi, guru, dan siswa dilaksanakan pada tanggal 15 November 2013 di SMK Negeri 3 Yogyakarta.

Subyek atau responden yang terlibat dalam penelitian ini adalah kepala bengkel, teknisi, guru, dan siswa yang berada di Bengkel Kerja SMK Negeri 3 Yogyakarta dan BLPT Yogyakarta. Jumlah responden pada saat analisis kebutuhan sebanyak 8 orang yang terdiri dari pengelola bengkel dan teknisi. Jumlah responden pada uji beta kelompok kecil sebanyak 14 orang responden, sedangkan jumlah responden uji coba produk atau penilaian produk sebanyak 28 orang.

Adapun model pengembangan sistem yang digunakan dalam penelitian ini adalah prototyping sebagai alternatif terhadap siklus daur hidup pengembangan sistem. Pertimbangan waktu yang lama dan biaya yang cukup tinggi pada sistem daur hidup, juga berkaitan dengan keinginan pengguna yang bisa berubah seiring dengan waktu (Kadir, 2003:416). Langkah-langkah yang dilakukan pada pengembangan prototype terdiri atas: 1) Analisis kebutuhan, 2) Desain produk, 3) Pengembangan desain produk, 4) Uji coba/implementasi produk, dan 5) Penilaian/validasi produk.

Secara keseluruhan prosedur pengembangan produk sistem informasi manajemen 
Bengkel Kerja SMK ini selengkapnya dapat

dilihat pada Gambar 3 berikut ini:

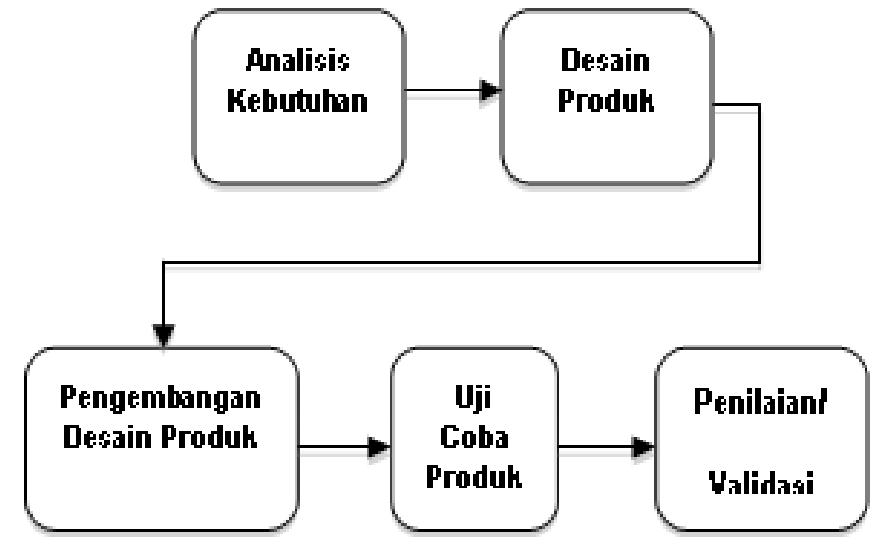

Gambar 3. Prosedur Pengembangan SIM Bengkel Kerja SMK

\section{Desain Uji Coba Produk}

Ada beberapa tahapan dalam uji coba produk:

(a) Uji ahli atau Validasi, dilakukan dengan responden para ahli perancangan model atau produk.

Kegiatan ini dilakukan untuk mereview produk awal, memberikan masukan untuk perbaikan. Proses validasi ini disebut dengan Expert Judgement atau Teknik Delphi; (b) Revisi I ; (c) Uji Coba Kelompok Kecil, atau Uji terbatas dilakukan terhadap kelompok kecil sebagai pengguna produk; (d) Revisi II; (e) Uji Coba Lapangan (field testing); (f) Revisi III; dan (g) Produk Akhir dan Diseminasi

Data, Intrumen, dan Teknik Pengumpulan Data

Metode dokumentasi yang berupa foto juga digunakan dalam penelitian ini yaitu untuk merekam kegiatan-kegiatan yang berlangsung selama penelitian. Penelitian ini menggunakan instrumen berbentuk angket, khususnya angket tertutup, angket jenis ini jawabannya sudah disediakan sehingga responden tinggal memilih jawaban yang mereka anggap benar atau sesuai.

Teknik analisis data kuantitatif dalam penelitian ini menggunakan statistik deskriptif, yang berupa pernyataan sangat baik, baik, sedang, tidak baik, dan sangat tidak baik yang diubah menjadi data kuantitatif dengan skala 5 yaitu dengan penskoran dari 1 sampai 5. Skor yang diperoleh kemudian dikonversi menggunakan acuan yang dikembangkan oleh (Sudijono, 2011:329-333)

Penelitian ini membahas tentang bagaimana merancang sistem informasi program atau software yang berfungsi untuk mendukung pelayanan administrasi Bengkel Kerja yang ada di SMK Negeri 3 Yogyakarta, baik itu SDM, peralatan, dan bahan praktik Bengkel Kerja SMK. Dalam mengembangkan sistem informasi tersebut koneksi databasenya adalah dengan menggunakan MySQL.

Langkah-langkah pengembangan desain produk yang dilakukan adalah: (1) Pembuatan entitas; (2) Pembuatan diagram konteks; (3) Pembuatan diagram alir data; (4) Pembuatan flowchart program; (5) Pembuatan relasi antar tabel.

Berikut ini merupakan hasil penelitian yang dijabarkan satu-persatu berdasarkan urutan menu yang tersedia.

\section{Masuk ke Sistem Informasi}

Form Entry Password ini berfungsi untuk login yang akan mengisi jadwal shift pada data storage. 


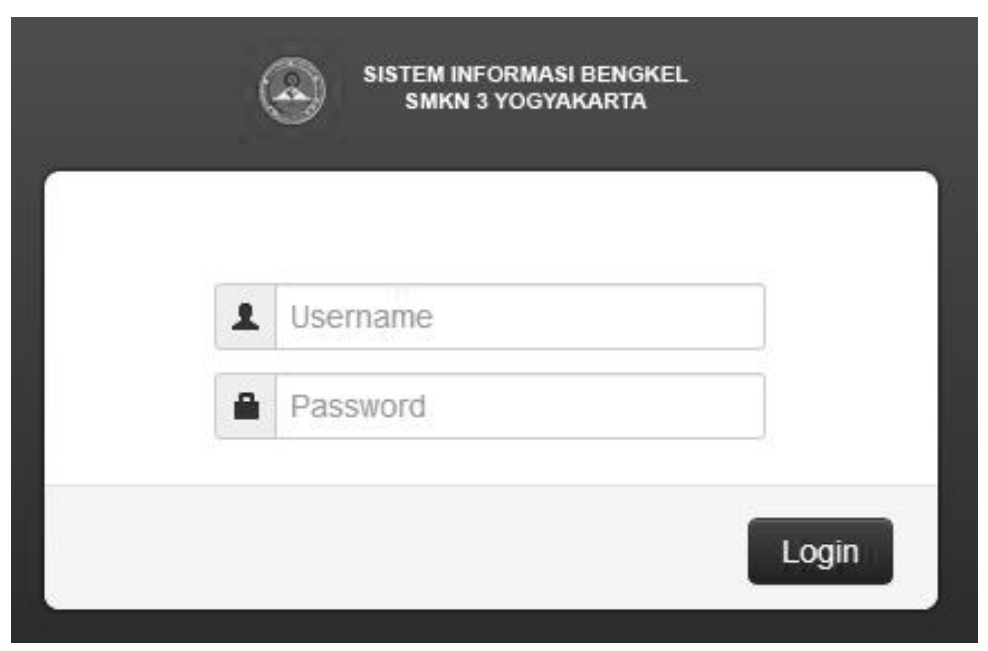

Gambar 4. Entry Password

\section{Tampilan Utama (Be randa)}

Program aplikasi untuk form utama lain akan diaktifkan dan melakukan proses SIMBA ini diberi judul "Beranda". Form ini pencatatan data. merupakan bagian terpenting dimana form-form

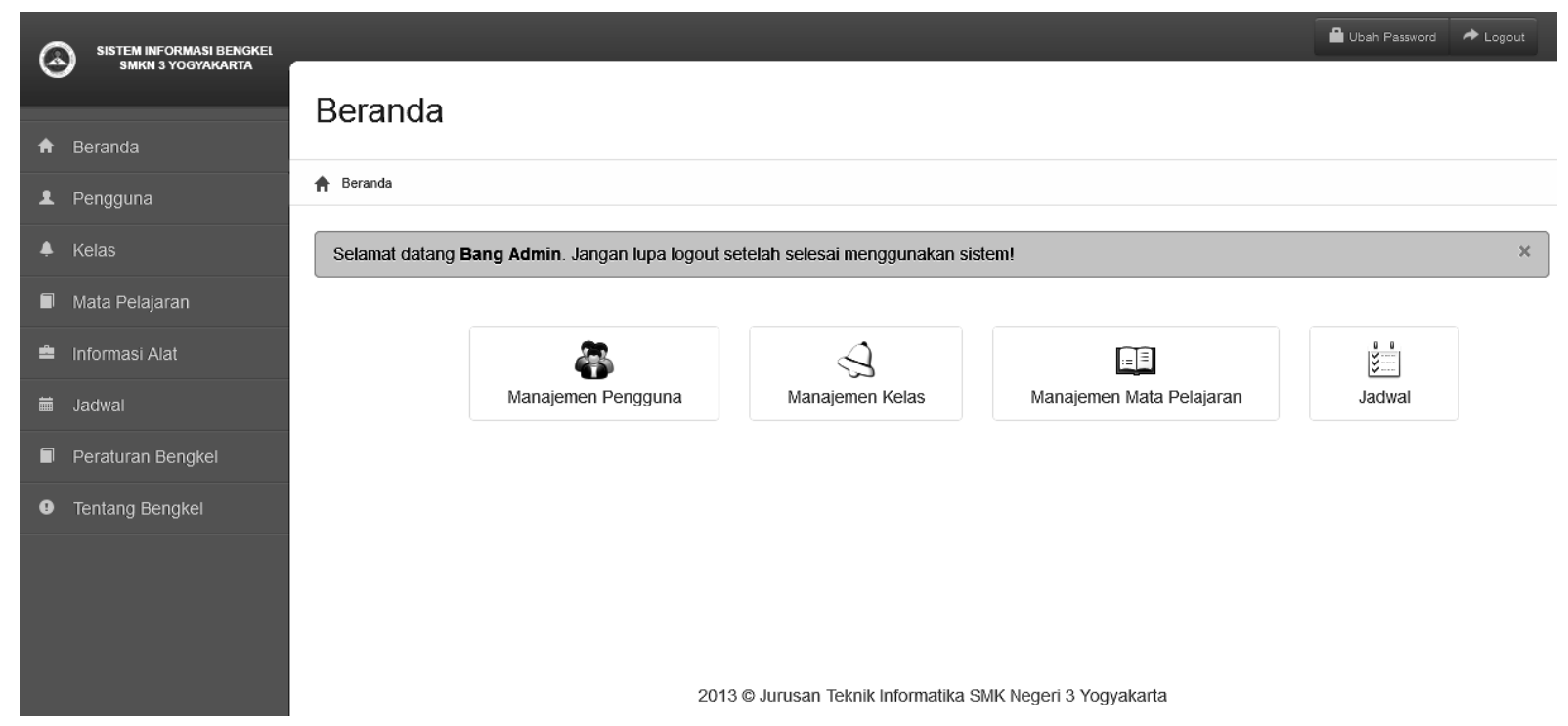

Gambar 5. Tampilan Utama (Beranda) 


\section{Menu Pengguna}

Form ini digunakan untuk pengguna. pengguna. Pengguna sebagai kepala bengkel, Form ini hanya aktif jika login sebagai guru, teknisi dan siswa.

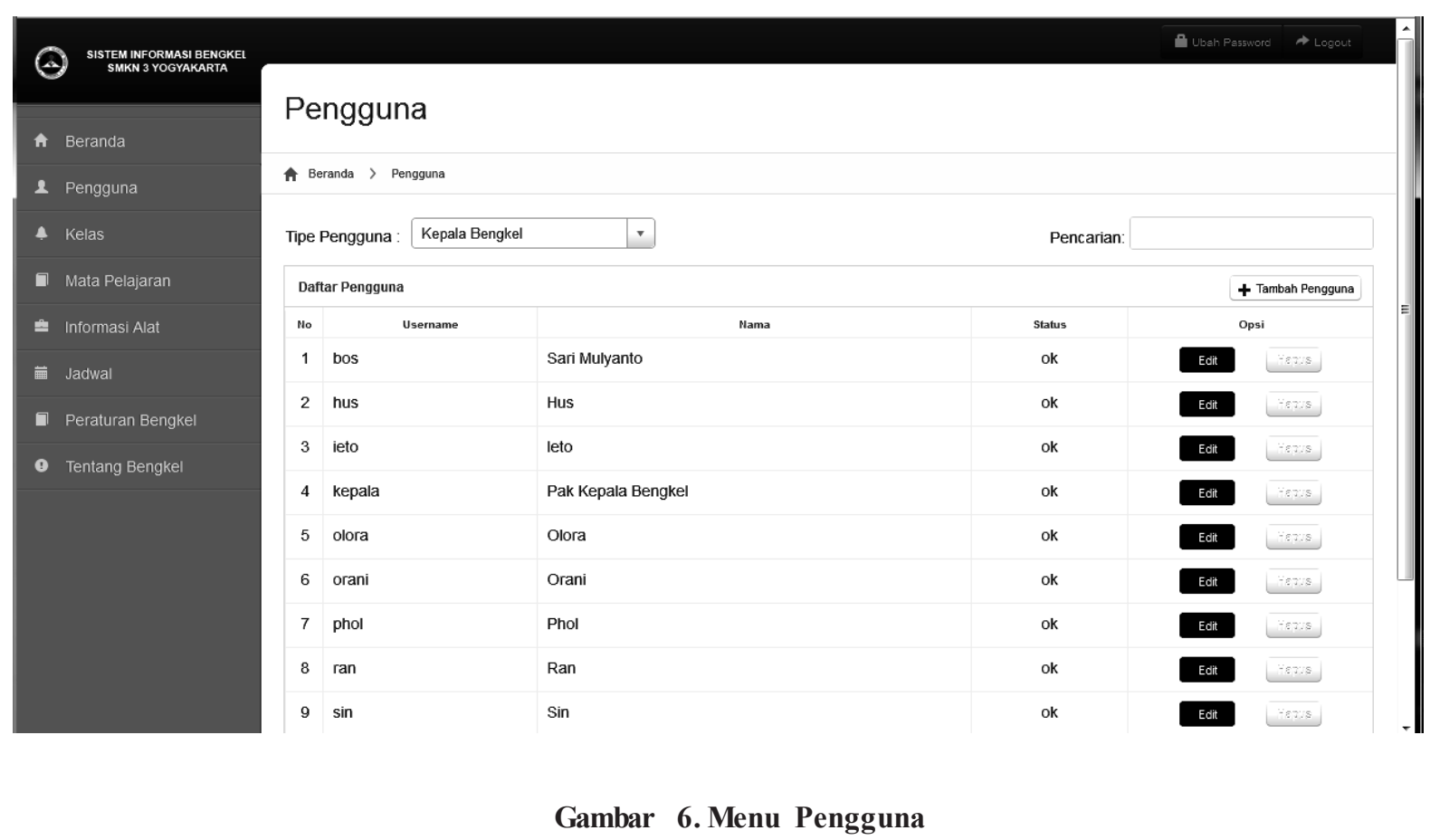

\section{Input Data Kelas}

Form ini digunakan untuk menambah Data Kelas.

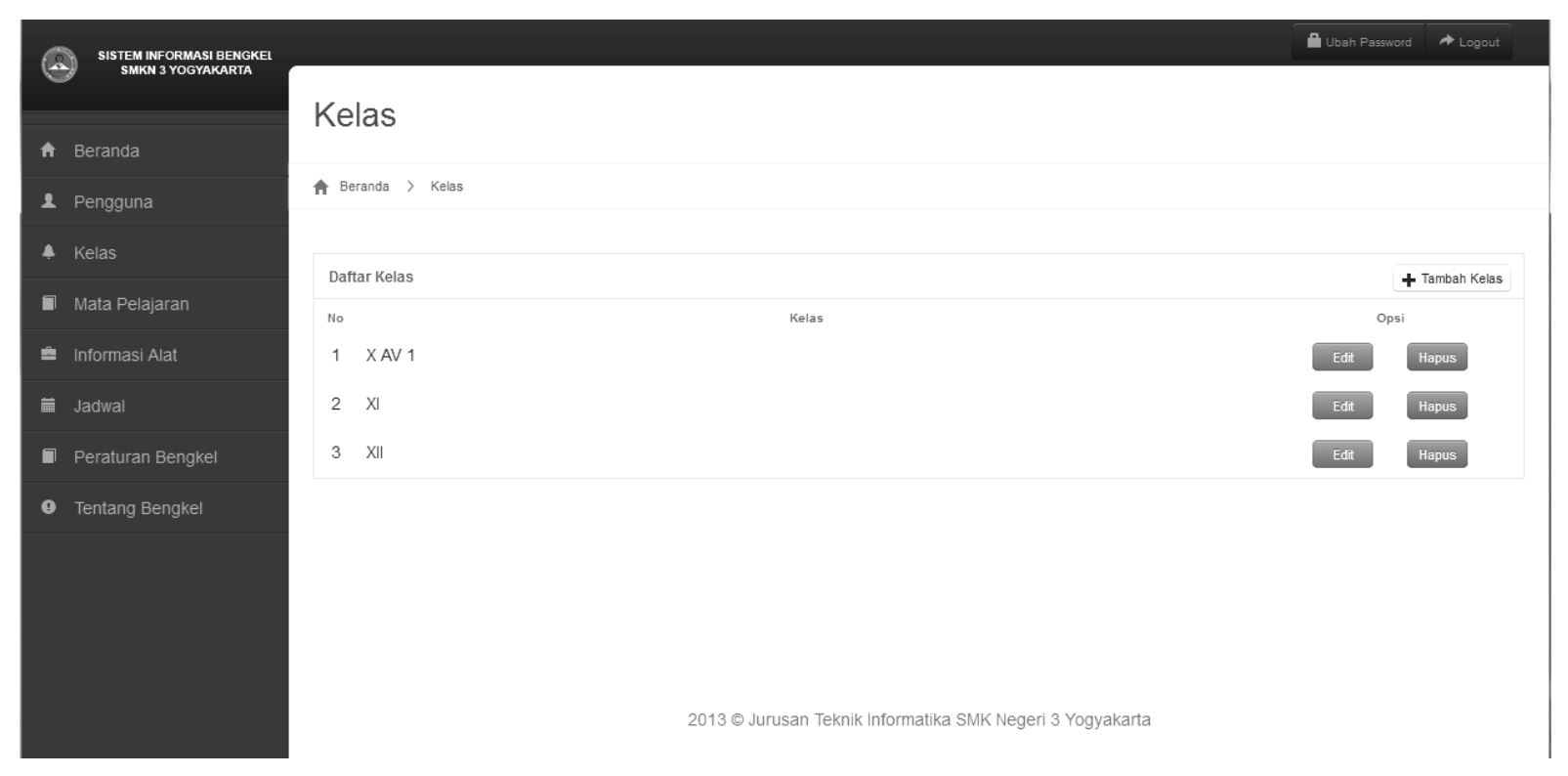


334 Jurnal Pendidikan Teknologi dan Kejuruan, Volume 22, Nomor 3, Mei 2015

\section{Input Data Mata Pelajaran}

Form ini digunakan untuk menambah Data Mata Pelajaran

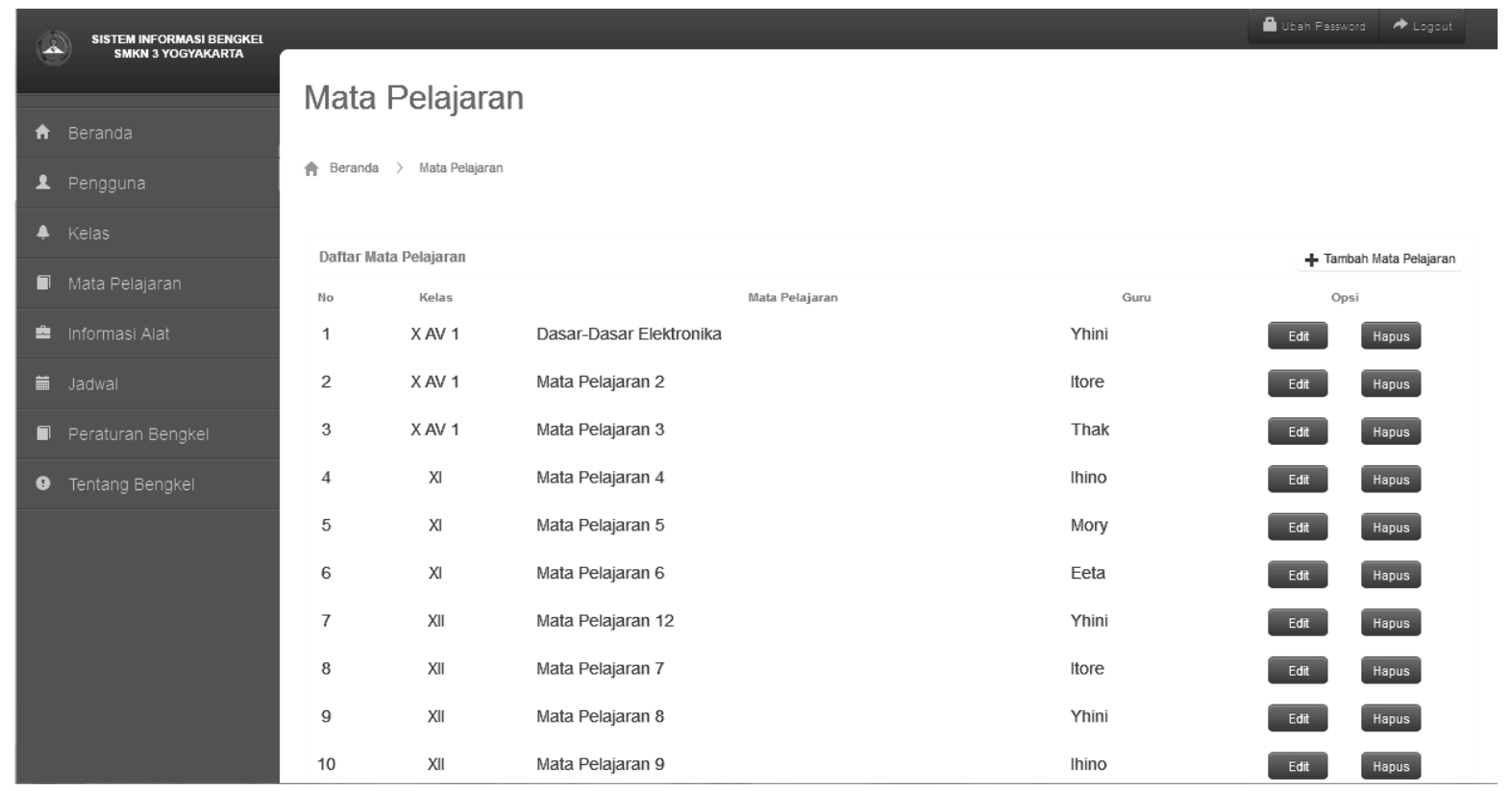

Gambar 8. Input Data Mata Pelajaran

\section{Informasi Alat}

Form ini digunakan untuk melihat, alat. Tombol hapus aktif jika login sebagai menambah, menghapus dan mengubah data Admin pada sistem.

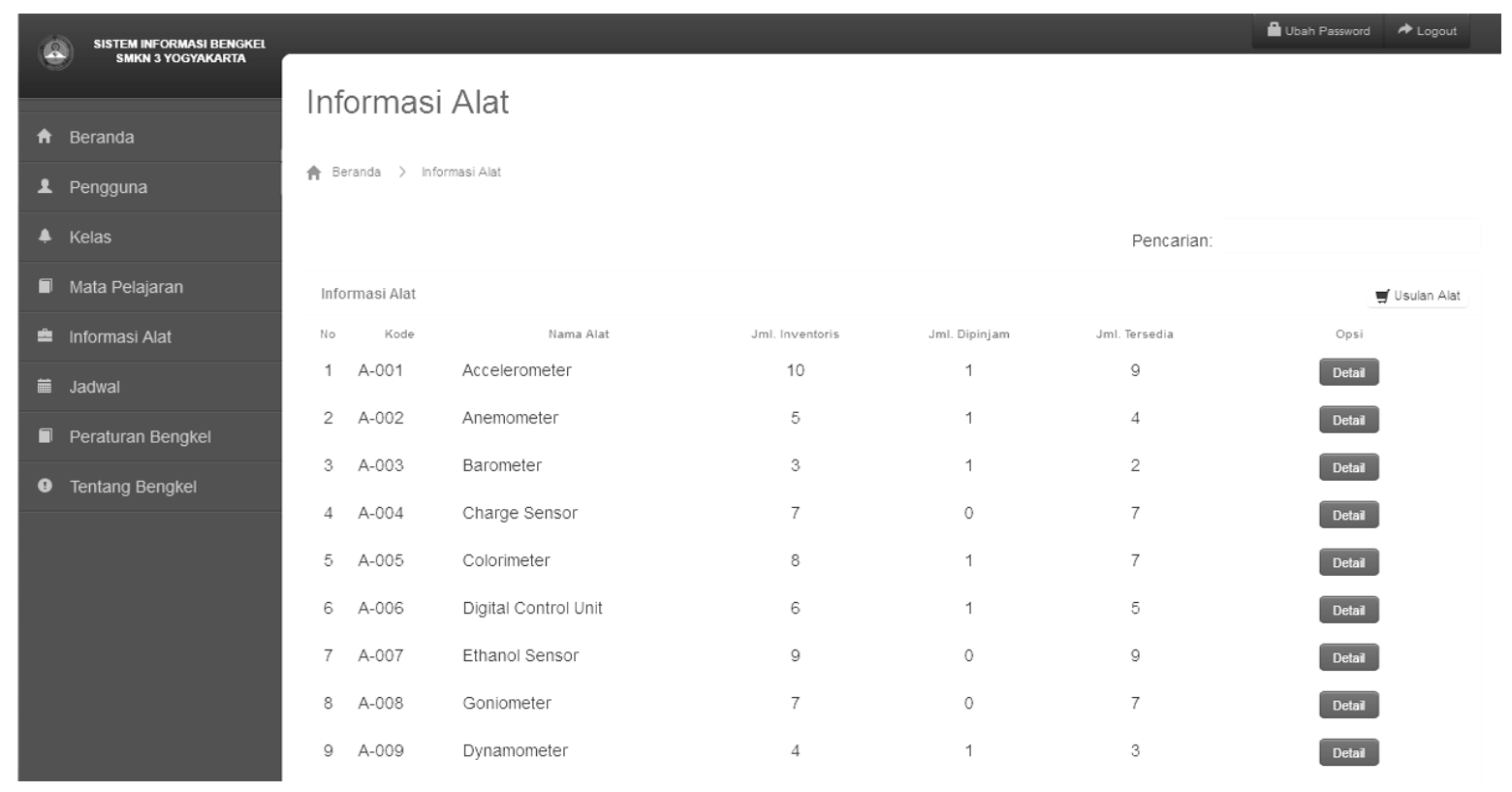

Gambar 9. Informasi Alat 


\section{Jadwal Praktikum}

Form ini digunakan untuk melihat, menambah, menghapus,dan mengubah data jadwal Praktikum.
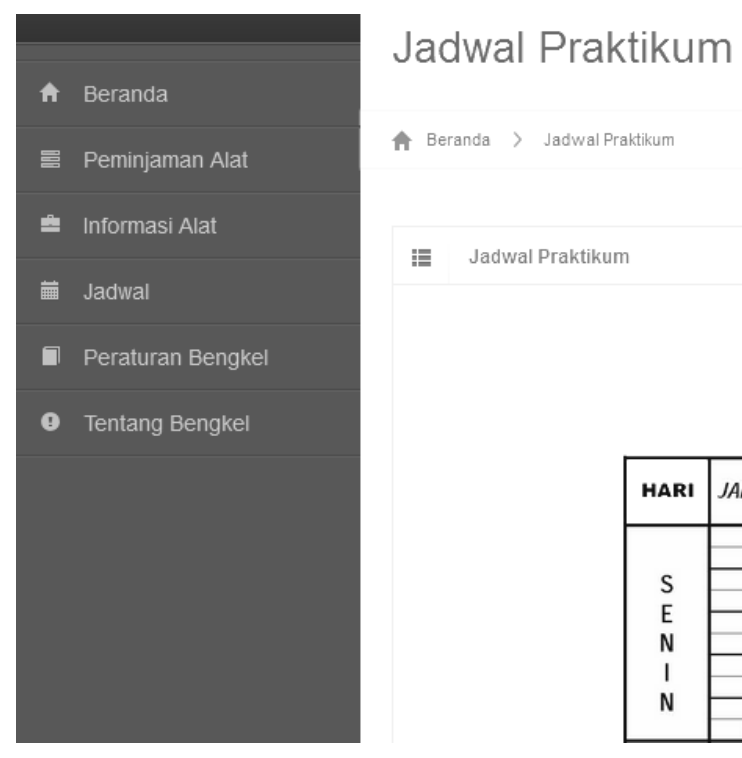

\begin{tabular}{|c|c|c|c|c|c|c|c|c|}
\hline \multirow{2}{*}{ HARI } & \multirow{2}{*}{$J A M K E$} & \multirow{2}{*}{ WAKTU } & \multicolumn{2}{|c|}{ KELAS X } & \multicolumn{2}{|c|}{ KELAS XI } & \multicolumn{2}{|c|}{ KELAS XII } \\
\hline & & & AV1 & AV2 & AV1 & AV2 & AV1 & AV2 \\
\hline \multirow{10}{*}{$\begin{array}{l}\mathrm{S} \\
\mathrm{E} \\
\mathrm{N} \\
\mathrm{I} \\
\mathrm{N}\end{array}$} & 1 & $07.00-0930$ & $\mathrm{TE}$ & BINDO & \begin{tabular}{l|l} 
TRV-ITV \\
\end{tabular} & $\overline{O R}$ & BING & MTK \\
\hline & 2 & & $111 / 1116$ & 17 & $112 / 114$ & 24 & 32 & 46 \\
\hline & 3 & & TE & FISIKA & TRV-ITV & MTK & MTK & KKPI \\
\hline & 4 & $09.30 \cdot 10.00$ & $111 / 116$ & 61 & $112 / 114$ & 42 & 45 & 84 \\
\hline & 5 & & GT.TP & SEJARAH & PCDP.CCR & B INDO & IPS & PAI \\
\hline & 6 & $10.15-11.45$ & $112 / 118$ & 74 & $\begin{array}{l}0 \\
110 / 117 \\
\end{array}$ & 20 & 73 & 3 \\
\hline & 7 & & GT-TP & MTK & B INDO & & PAl & B ING \\
\hline & 8 & $12.15-13.45$ & $112 / 118$ & 52 & 20 & & 3 & 32 \\
\hline & 9 & $13.45-15.15$ & SNB & & & & & \\
\hline & 10 & $13.45-15.15$ & 27 & & & & & \\
\hline
\end{tabular}

\section{Gambar 10. Jadwal Praktikum}

\section{Peraturan Bengkel}

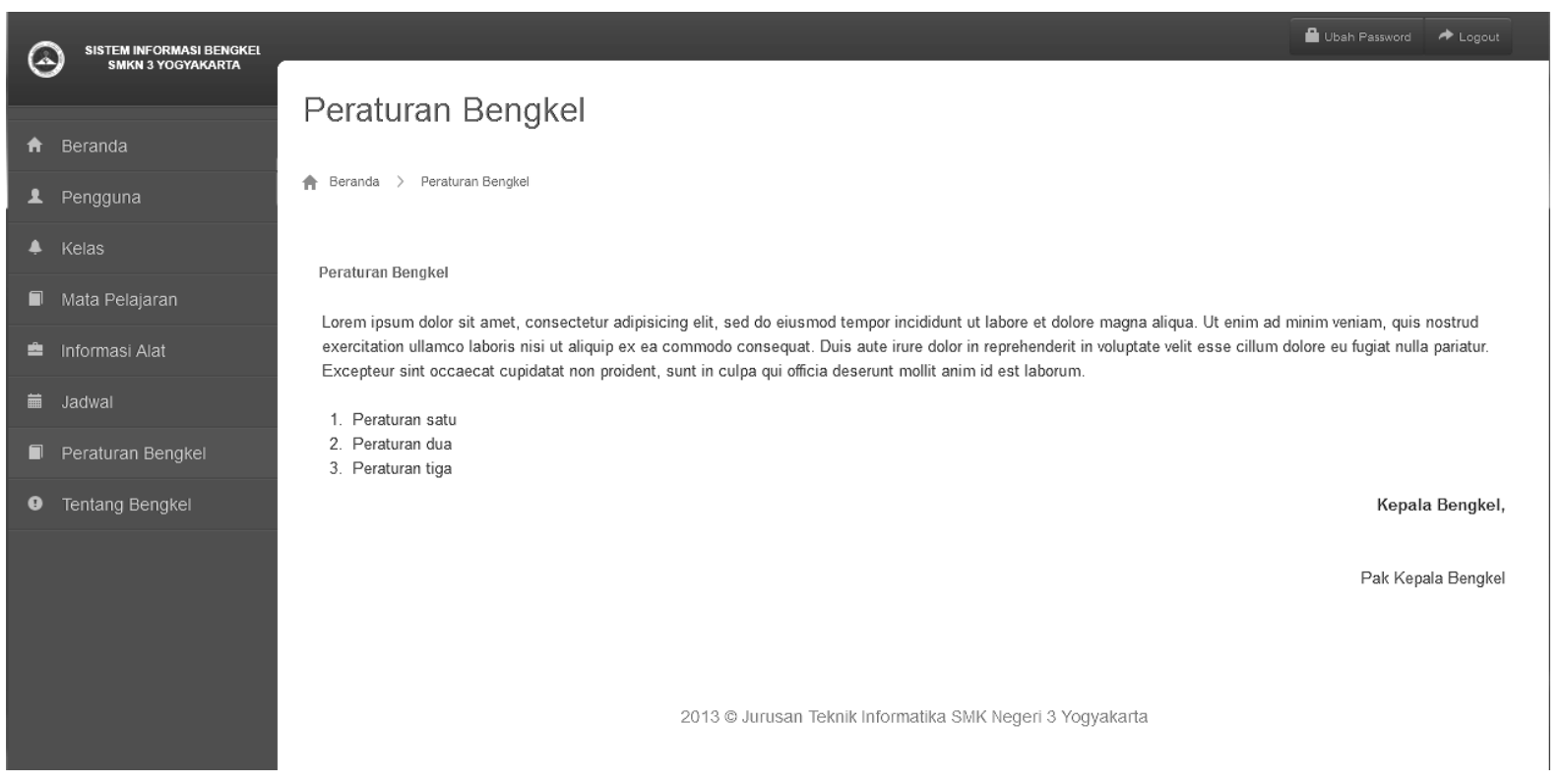

Gambar 11. Peraturan Bengkel 


\section{Tentang Bengkel}

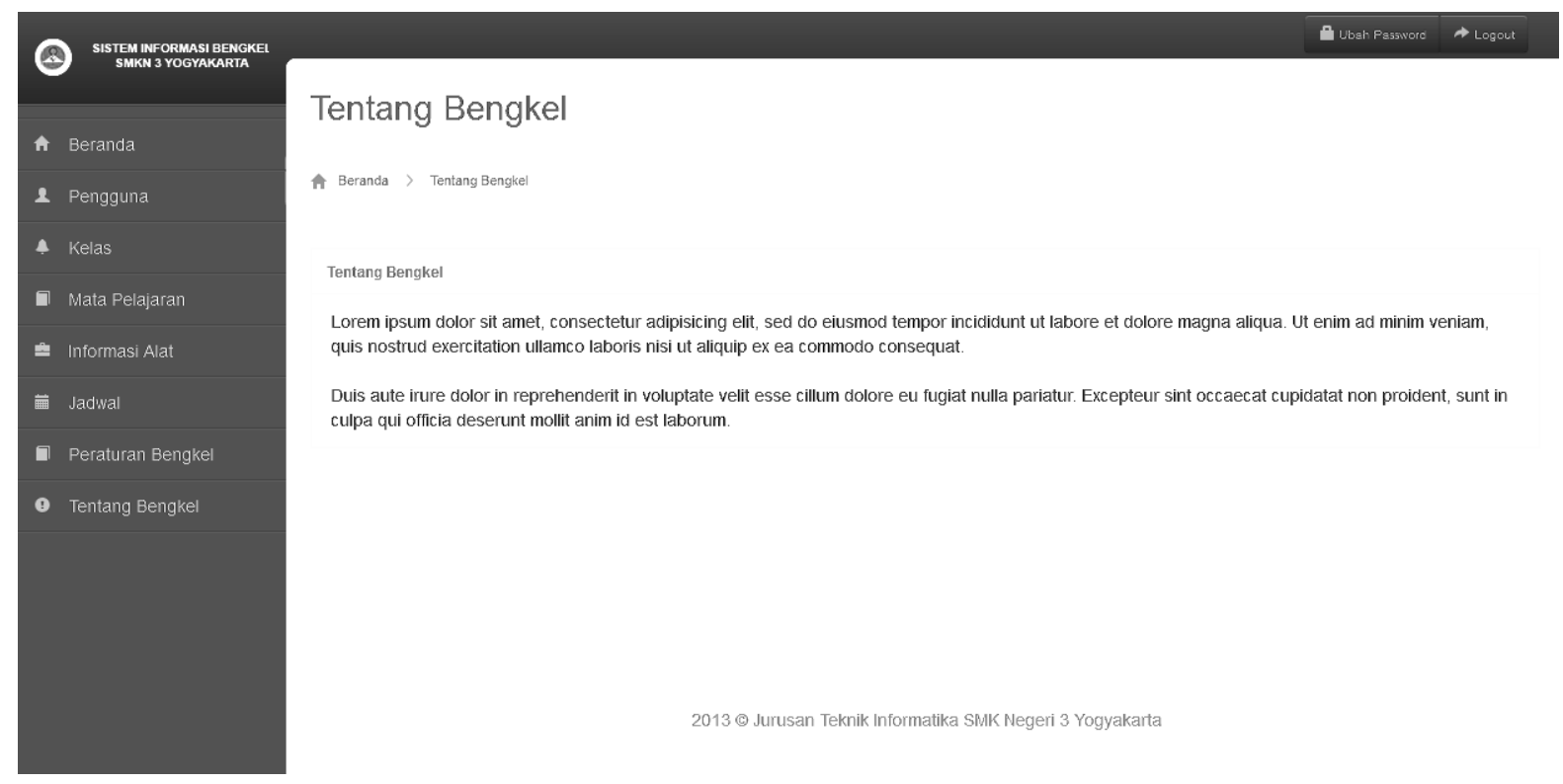

Gambar 12. Tentang Bengkel

Produk yang telah dibuat digunakan oleh para pengguna yaitu kepala bengkel, teknisi, guru, dan siswa, untuk melakukan transaksi menggunakan produk tersebut. Produk yang telah dibuat digunakan dan ternyata tidak mengalami gangguan dan dapat berjalan sebagaimana mestinya meskipun ada unjuk kerja beberapa fitur yang belum maksimal. Salah satu kekurangan yang ditemukan yaitu langkah penginstalan software yang panjang sehingga memerlukan seorang ahli pemrograman untuk melakukan penginstalan software.

Setelah selesai mengimplementasikan produk maka tahap selanjutnya para pengguna diberikan kesempatan untuk memberikan tanggapan terhadap produk yang telah dibuat. Tanggapan tersebut meliputi beberapa aspek yaitu aspek kejelasan dan konsistensi, keakuratan, dan keandalan. Dengan mengamati dan mencatat hasil uji coba produk yang telah dilakukan oleh user/pengguna maka didapatkan hasil tentang penilaian penggunaan produk dari aspek kejelasan dan konsistensi, keakuratan, dan keandalan yang dapat dilihat seperti tabel 1 berikut:

\section{Aspek Kejelasan dan Konsis tensi}

Berdasarkan pengisian angket yang dilakukan oleh pengguna yang kemudian ditabulasikan maka data yang berkaitan dengan aspek tampilan program dapat dianalisis sehingga didapatkan hasil seperti tabel 1 berikut:

\section{Tabel 1. Penilaian Terhadap Aspek Kejelasan} dan Konsistensi

\begin{tabular}{|c|c|c|c|c|c|c|}
\hline \multirow{2}{*}{ No. } & \multirow{2}{*}{ ASPEK PENILAIAN } & \multicolumn{5}{|c|}{ NILAI } \\
\hline & & 1 & 2 & 3 & 4 & 5 \\
\hline \multicolumn{7}{|c|}{ A. A SPEK KEJELA SAN \& KONSISTENSI } \\
\hline 1 & Kejelasan petunjuk penggunaan SIM Bergkel & 0 & 0 & 3 & 10 & 1 \\
\hline 2 & Kejelasan petınjuk irput data/ pengkodean & 0 & 0 & 2 & 12 & 1 \\
\hline 3 & Kejelasandalam proses memilih mern & 0 & 1 & 3 & 8 & 2 \\
\hline 4 & $\begin{array}{l}\text { Komposis } 1 \text { wama yarg digunakan do se tap } \\
\text { form sama }\end{array}$ & 0 & 0 & 5 & 7 & 2 \\
\hline 5 & Des ain form yarg ada di setiap forms ama & 0 & 0 & 2 & 9 & 3 \\
\hline 6 & $\begin{array}{l}\text { Jeris luruf yang digunakan di setiapform } \\
\text { sama }\end{array}$ & 0 & 0 & 1 & 9 & 4 \\
\hline 7 & $\begin{array}{l}\text { Ukuran luruf yang digunakan di setiapform } \\
\text { sama }\end{array}$ & 0 & 0 & 2 & 10 & 2 \\
\hline 8 & $\begin{array}{l}\text { Des ain tabel meru yarg ada di setiap form } \\
\text { sama }\end{array}$ & 0 & 2 & 7 & 2 & 3 \\
\hline 9 & $\begin{array}{l}\text { Tata letak tonbol yang ada disetiap form } \\
\text { sama }\end{array}$ & 0 & 0 & 2 & 8 & 4 \\
\hline 10 & $\begin{array}{c}\text { Des ain tampilan yang ad a di setiap form sama } \\
\text { Jumlah }\end{array}$ & $\begin{array}{l}0 \\
0\end{array}$ & $\begin{array}{l}0 \\
3\end{array}$ & $\begin{array}{c}3 \\
30\end{array}$ & $\begin{array}{c}8 \\
83\end{array}$ & $\frac{3}{25}$ \\
\hline & Jumlah X Skor Perilaian & 0 & 6 & 90 & 332 & 125 \\
\hline & Jumlah Total & & & & & \\
\hline & Rerata (X) & & & & & \\
\hline & Kesimpulan & & & & & \\
\hline
\end{tabular}

Berdasarkan tabel hasil penilaian aspek kejelasan dan konsistensi di atas maka dapat diketahui bahwa angka rerata yang diperoleh menunjukkan 3,95 dan apabila angka tersebut 
dikonversi menggunakan Tabel Pedoman Hasil Konversi Data Kuantitatif ke Data Kualitatif di atas maka termasuk dalam kategori Baik.

Setelah proses pengembangan sistem dilakukan mulai dari menyiapkan petunjuk penggunaan sistem informasi manajemen Bengkel Kerja SMK, proses pengumpulan data di lapangan, perancangan sistem telah dikerjakan maka tahap selanjutnya adalah tahap pembuatan program. Pembuatan program koneksi datanya menggunakan MySQL. Berdasarkan angket yang telah diisi yang kemudian ditabulasikan maka data yang berkaitan dengan aspek keakuratan dapat dianalisis sehingga didapatkan hasil seperti tabel 2 berikut:

Tabel 2. Penilaian Terhadap Aspek Keakuratan

\begin{tabular}{|c|c|c|c|c|c|c|}
\hline \multirow{2}{*}{ No } & \multirow{2}{*}{ ASPEK PENLAIAN } & \multicolumn{5}{|c|}{ NLAI } \\
\hline & & 1 & 2 & 3 & 4 & 5 \\
\hline \multicolumn{7}{|c|}{ B. ASPEK KEAKURATAN } \\
\hline 1 & Siste m keamanan data (password) akurat dalam bekerja & 0 & 0 & 3 & 6 & 5 \\
\hline 2 & $\begin{array}{l}\text { Siste m manqu menamb ah, menb ah, dan menghapus } \\
\text { tampilan'nama irstarsi sesuai dergan kata kunci }\end{array}$ & 2 & 0 & 2 & 8 & 2 \\
\hline 3 & $\begin{array}{l}\text { Sistem manqu memasukkandata tran alsiserai } \\
\text { dengan datainformasi yarg sebenamya }\end{array}$ & 0 & 0 & 3 & 9 & 2 \\
\hline 4 & $\begin{array}{l}\text { Sistem marqu melakukan pelacakan/percarian } \\
\text { barang/peralatan seruai dergan kata kunci. }\end{array}$ & 1 & 2 & 1 & 6 & 4 \\
\hline 5 & $\begin{array}{l}\text { Siste m marqu membuatlaporan sesuaidengan } \\
\text { data/informasi yang sebenamya }\end{array}$ & 2 & 3 & 5 & 2 & 2 \\
\hline & Jumlah & 5 & 5 & 14 & 31 & 15 \\
\hline & JumlahX S kor Perilaian & 5 & 10 & 42 & 124 & 75 \\
\hline & Jumlah Total & & & 286 & & \\
\hline & $\operatorname{Rerata}(\mathrm{X})$ & & & 3.66 & & \\
\hline & Kesirpulan & & & Baik & & \\
\hline
\end{tabular}

Berdasarkan tabel hasil penilaian aspek keakuratan di atas maka dapat diketahui bahwa angka rerata yang diperoleh menunjukkan 3,66 dan apabila angka tersebut dikonversi menggunakan Tabel Pedoman Hasil Konversi Data Kuantitatif ke Data Kualitatif di atas maka termasuk dalam kategori Baik.

Berdasarkan angket yang telah diisi yang kemudian ditabulasikan maka data yang berkaitan dengan aspek keandalan dapat dianalisis sehingga didapatkan hasil seperti tabel 3 berikut:
Tabel 3. Penilaian Terhadap Aspek Keandalan

\begin{tabular}{|c|c|c|c|c|c|c|}
\hline \multirow{2}{*}{ No. } & \multirow{2}{*}{ ASPEK PENLAIAN } & \multicolumn{5}{|c|}{ NILAI } \\
\hline & & 1 & 2 & 3 & 4 & 5 \\
\hline \multicolumn{7}{|c|}{ C. Aspek Keandahn } \\
\hline 1 & $\begin{array}{l}\text { Sitem yang dibu at dapat mengatasi masalah } \\
\text { pe kyman administrasi bengkelk erja praktik }\end{array}$ & 0 & 0 & 4 & 8 & 2 \\
\hline 2 & $\begin{array}{l}\text { Sitem yaing dibuat dapat mengatasimasalah lapor on } \\
\text { inventarisasi alat, bahar, mesm }\end{array}$ & 0 & 0 & 4 & 7 & 3 \\
\hline 3 & $\begin{array}{l}\text { Sitem yamg dibuat dapat mengat ssimasalah lapor am } \\
\text { peminjaman dan pengembalian alat, baham, me sin }\end{array}$ & 0 & 0 & 3 & 8 & 3 \\
\hline 4 & $\begin{array}{l}\text { Sitem yang dibuat dapat mengatasimasalah lapor an } \\
\text { pengadam alat, bahan, mesin }\end{array}$ & 0 & 1 & 6 & $s$ & 2 \\
\hline$s$ & $\begin{array}{l}\text { Sitem youg dibuat dapat mengatasimasalah lapor an } \\
\text { peryimpanam alat, baham, mesin }\end{array}$ & 0 & 0 & 7 & 4 & 3 \\
\hline 6 & 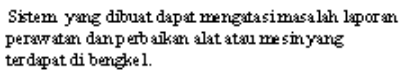 & 0 & 3 & 4 & 6 & 1 \\
\hline 7 & 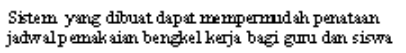 & 0 & 1 & 3 & 8 & 2 \\
\hline 8 & $\begin{array}{l}\text { Sitem yong dibuat dapat dijalankan dengam mudah } \\
\text { oleh pengelola dan teknisi } \\
\text { Sitem yomg dibuat dapat me lakukan pengolaham }\end{array}$ & 0 & 0 & 2 & 5 & 6 \\
\hline 9 & $\begin{array}{l}\text { data yang cepat dibandingkan dengan car a } \\
\text { marroulbiast. } \\
\text { Sitem yang dibuat dapat membartu kerja penge lola }\end{array}$ & 0 & 0 & 2 & 7 & 5 \\
\hline 10 & 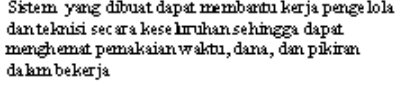 & 0 & 1 & 0 & 12 & 1 \\
\hline 11 & $\begin{array}{l}\text { Sitem yang dibuat dapat meringkatkanmuntu } \\
\text { pe hyman penge lola bengke lkepada siwas kar ena } \\
\text { datu irf ommasi dapat di akses dengan cepat }\end{array}$ & 0 & 0 & 0 & 14 & 0 \\
\hline 12 & $\begin{array}{l}\text { Inf ormasi yang diperoleh dari sistem informasi } \\
\text { manajemen sering digunakan dalam proses } \\
\text { pengembilm keputussm }\end{array}$ & 0 & 0 & 5 & 8 & 1 \\
\hline & Jumlah & 0 & 6 & 40 & 92 & 29 \\
\hline & Jumlah X S kor Perilaian & 0 & 12 & 120 & 368 & 145 \\
\hline & Jumlah Total & & & 645 & & \\
\hline & Rerata (X) & & & 3.84 & & \\
\hline & Kesinqulan & & & Baik & & \\
\hline
\end{tabular}

Berdasarkan tabel hasil penilaian aspek Keandalan di atas maka dapat diketahui bahwa angka rerata yang diperoleh menunjukkan 3,84 dan apabila angka tersebut dikonversi menggunakan Tabel Pedoman Hasil Konversi Data Kuantitatif ke Data Kualitatif di atas maka termasuk dalam kategori Baik.

Hasil penilaian produk secara keseluruhan dapat dilihat pada tabel 4 berikut:

Tabel 4. Penilaian Program Secara Keseluruhan

\begin{tabular}{|c|c|c|c|c|c|c|}
\hline \multirow{2}{*}{ No } & \multirow{2}{*}{$\begin{array}{c}\text { ASPEK } \\
\text { PENILAIAN }\end{array}$} & \multicolumn{5}{|c|}{ NILAI } \\
\hline & & 1 & 2 & 3 & 4 & 5 \\
\hline 1 & $\begin{array}{l}\text { Aspek Kejelasan } \\
\text { dan Konsistensi }\end{array}$ & 0 & 3 & 30 & 83 & 25 \\
\hline 2 & Aspek Relevansi & 5 & 5 & 14 & 31 & 15 \\
\hline \multirow[t]{2}{*}{3} & Aspek Keandalan & 0 & 6 & 40 & 92 & 29 \\
\hline & Jumlah & 5 & 14 & 84 & 206 & 69 \\
\hline \multicolumn{2}{|c|}{ Jumlah X Skor Penilaian } & 5 & 28 & 252 & 824 & 345 \\
\hline & Jumlah Total & \multicolumn{5}{|c|}{1454} \\
\hline & Rerata (X) & \multicolumn{5}{|c|}{3.85} \\
\hline & Kesimpulan & \multicolumn{5}{|c|}{ BAIK } \\
\hline
\end{tabular}

Berdasarkan tabel hasil penilaian program secara keseluruhan di atas maka dapat diketahui bahwa angka rerata yang diperoleh menunjukkan 3,85 dan apabila angka tersebut 
dikonversi menggunakan Tabel Pedoman Hasil Konversi Data Kuantitatif ke Data Kualitatif di atas maka termasuk dalam kategori Baik.

\section{SIMPULAN}

Sebuah produk berupa Software yang diberi nama "Sistem Informasi Manajemen Bengkel Kerja SMK Negeri 3 Yogyakarta" atau disingkat dengan "SIMBA SMK Negeri 3 Yogyakarta" telah berhasil dirancang dan diimplementasikan sesuai dengan kebutuhan SMK Negeri 3 Yogyakarta dengan sistem manajemen database Visual Basic. 6.0. sebagai piranti lunak untuk membangun tampilan, Sedangkan koneksi yang digunakan untuk pembuatan databasenya adalah dengan menggunakan $M y S Q L$.

Sistem Informasi Manajemen Bengkel Kerja SMK ini berhasil dalam menjalankan fungsi sesuai dengan yang ditentukan. Hasil rerata skor penilaian secara keseluruhan terhadap semua aspek mencapai nilai 3,77, termasuk dalam kategori baik. Sistem informasi ini belum dapat diakses komputer lain melalui jaringan atau hanya bersifat lokal sehingga data-data yang ada dalam sistem informasi tidak dapat diakses komputer lain secara online sehingga dalam penelitian dan pengembangan selanjutnya dapat ditambahkan agar data-data yang ada dalam sistem informasi dapat diakses oleh komputer lain dalam satu jaringan atau lebih.

\section{DAFTAR RUJUKAN}

Kadir, A. 2003. Pengenalan Sistem Informasi. Yogyakarta: Andi Offset

Berte, L. M. 2007. Laboratory Quality Management: A Roadmap. Journal of management workshop or laboratory. 777, 771-790. Diunduh tanggal 16 September 2013, dari http://supra. amu.edu.pl/files/analityczna/LQM Road map.pdf
Borg, Walter. R and Gall, Meredith D. 1983. Educational Research : an introducton $\left(4^{\text {th }} e d\right)$. New York \& London: Longman Inc

Budi Sutedjo D. O. 2002. Perencanaan \& Pembangunan Sistem Informasi. Yogyakar-ta: Andi Offset

Depdiknas. 1989. Undang-Undang Republik Indonesia No.2, Tahun 1989, tentang Sistem Pendidikan Nasional

Depdiknas. 1990. Peraturan Pemerintah No.29 Tahun 1990, tentang tujuan Sekolah Menengah Kejuruan

Depdiknas. 1990. Peraturan Pemerintah No.24 Tahun 1990, tentang tujuan Sekolah Menengah Kejuruan

Joel Tadjo. 1995. Pedoman Umum Penyelenggaraan Bengkel . Bandung : Direktorat Pendidikan Menengah Kejuruan

Kristanto, Andri. 2008. Perancangan Sistem Informasi dan Aplikasinya. Yogyakarta: Gava Media

Reddy, G. S. 2009. Management information system to help managers for providing decision making in an organization. Journal of Management information system. 1, 2076-3328. Diunduh tanggal 16 September 2013, dari http:// www.ijric.org/volumes/Vol5/1Vol5.pdf

Sutanta, E. 2003. Sistem Informasi Manajemen. Yogyakarta : Graha Ilmu

Wenrich, R. C \& Wenrich, J. W. 1974. Leadership in Administration of Vocational and Technical Education. Ohio: Charles E. Merrill Publishing Co. A Bell \& Howell Company 